\title{
The Configuration of Reference in an Electronic Environment
}

\author{
Jane P. Kleiner
}

\begin{abstract}
Administrators often look at the centralization of library collections and services as a means of improving finances, space availability, and user access. The effect on personnel, however, is seldom given equal attention. This article reviews both the positive and negative impact of centralization on staff and service. It describes the benefits of the central mode for professional development. The move from decentralized to centralized library service at Louisiana State University is discussed, as well as the effect of automation on that configuration.
\end{abstract}

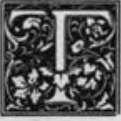

he centralization versus decentralization argument regarding the configuration of libraries and collections has been subjected to decades of debate in the professional literature. Opposing views on academic library organization began appearing in the $1930 \mathrm{~s}$ and $1940 \mathrm{~s}$. Since then, numerous papers have been published addressing the question. Entire conferences have argued the pros and cons of the alternative models.

Maurice Tauber described the issue a quarter of a century ago as "a significant topic for periodic re-examination. "' Keyes Metcalf reasoned: "As long as there are universities with large libraries, the question of centralization or decentralization will be a live topic for discussion, and, if I am not mistaken, the question will never be settled permanently one way or the other." 2

Early library organization followed a highly centralized design. Administration in large academic libraries was mostly central until World War II. Administrative problems were created by expanding collections and staff, so that other organizational patterns began to emerge. College and university libraries began organizing along departmental lines in the 1940 s with work divided among circulation, reference, and cataloging.

In 1947, Rose Phelps described a library organization form in which reference was provided in "a subject departmentation" mode within the central organization. Her study compared reference service organizational patterns in three large public libraries. In it, she discussed the advantages and disadvantages of each model, concluding that subject organization provided superior reference assistance to patrons, though she did point out that such designs usually required separate general reference departments for ready reference and information service. ${ }^{4}$

During this same period and in the following decade, librarians increasingly incorporated the concept of function in designing libraries and providing services. Raynard C. Swank promoted the educational function concept and its relationship to library planning. He subscribed to the divisional plan as the most educationally efficient design. That plan's tenets divided all functions of the library, except administration and technical processes, into subject areas-social sciences, humanities, and science and technology.

Jane P. Kleiner is Head, Reference Services, at Troy H. Middleton Library, Louisiana State University, Baton Rouge, Louisiana 70808. 
J. R. Blanchard carried the subject concept a step further by proposing that librarians in "divisional reading rooms" be subject specialists rather than reference or circulation librarians. ${ }^{6}$

\section{STAFF SPECIALIZATION}

While this debate was in progress, librarians were arguing for staff specialization instead of subject specialization. Lyle pointed to Peyton Hurt's argument that reference librarians should specialize in the history and bibliography of a field through systematic study of the literature rather than through experience gained in working with a subject collection.?

Lyle agreed with Hurt but also recognized the importance of specialization in university library work, particularly in dealing with graduate students and faculty. He did, however, caution the profession about excessive emphasis on the value of specialization when providing library service to undergraduates. Lyle pointed to the importance of general reference specialization over subject specialization in dealing with the undergraduate population. He argued that that category of user was served more effectively when "the reference librarian has the breadth of knowledge and human understanding to feel a real interest in the inquirer's needs. Narrow concentration in a field does not necessarily contribute to this idea. While it is proper and undoubtedly important that the reference librarian have special interests-a diversity of interest is all to the good-a concentration of study in one field may impair his understanding of undergraduate students. ${ }^{\prime 8}$

In the 1960 s and 1970 s, interest soared in this pattern of decentralization as numerous separate libraries for undergraduates were established. Interest in that organizational mode has diminished in recent years due to a variety of factors: improved library instruction methods, declining financial resources, and reduced enrollments. ${ }^{9}$

Against this backdrop of debate, new arguments have emerged focusing on the impact of technology on library organization. At a 1983 symposium on the topic, Anne Woodsworth argued: "When to- day's technology is utilized fully, the issue of centralized collections will fade into oblivion. It will no longer matter."10 Atkinson agreed with that concept in his prediction that the academic organizational pattern of the future is likely to be decentralized. ${ }^{11}$

Edward Holley, however, raised the question of users' demands for ' 'better access to more and more materials" in responding to the viewpoint that technology could result in decentralization. He urged careful consideration of "service needs, the administrative organization, and the fiscal impact of this centralization vs. decentralization argument."'12

Martell proposed a plan that addressed the question of meeting library users' needs-a library organized into small client-centered work groups with librarians operating at all points where "the library interacts with its user groups. ${ }^{\prime 13}$ In this organization, each work-group member would perform a variety of library functions such as advanced reference, collection development, bibliographic instruction, original cataloging, plus other types of information service. Martell asserted that this model would be more responsive to users' needs.

\section{TECHNOLOGY EFFECTS}

In The Electronic Library: The Impact of Automation on Academic Libraries, Cline and Sinnott suggested a type of matrix management as the organizational mode, the physical design being drawn along subject divisional lines. ${ }^{14}$ Others offer few concrete plans for the physical organization. Instead, they challenge librarians to view their environments as information centers, knowledge bases, or communities of scholars, rather than as storehouses of books.

Patricia Battin urged universities to explore the joint roles of computer centers and libraries as information handlers. She recommended integrating information technology into the existing information system to preserve the linkages to the present knowledge base. "The very diversity of scholarly inquiry and information needs requires in the electronic age an unprecedented degree of centralized, coordi- 
nated linkages and compatibilities to serve that diversity and permit the autonomy necessary for productive and creative scholarship," Battin asserted. ${ }^{15}$

Richard McCoy voiced a similar philosophy when he called for an end to campus information compartmentalization. He urged libraries to adopt a new and broader information role when he said, "Today's research library is and must be a gateway to the broadest world of scholarly information, regardless of the information's format or source. It must be a channel to machine-readable databases and to sound and image data, as well as to books and periodicals. It must be the facilitator for access to the combined information of private, for-profit resources, as well as those of the public and educational sectors. It must be a channel linking scholars with the local, national, and international resources required to support their best work." 16

Though the centralization-decentralization debate has been waged for more than half a century, a resolution seems no nearer today. Indeed, the added dimension of electronic information in libraries makes the question more complex. This paper provides no immediate solution to the organizational dilemma. Instead, it proposes centralizing one library service: reference. It explores the advantages and disadvantages of the service and staffing aspects of a centralized model and focuses on the quality of information assistance and personnel that can be provided in that setting in an electronic environment. A number of arguments related to the broader centralization-decentralization issue and the impact of technology on the organization are applied to the discussion of the reference operation.

\section{DEFINITION OF CONCEPTS}

The ALA Glossary of Library and Information Science defines organizational centralization as "an organizational arrangement within a library system which is characterized by consolidated collections and service points in one central facility with few, if any, separate libraries outside that facility. "17 The glossary describes decentralization as "An organizational arrange- ment within a library system which is characterized by numerous geographically dispersed collections and service points."'

\section{"Different interpretations of central- ization in libraries and in the design of library services according to func- tion have existed through the years."}

Webster's Third New International Dictionary defines centralization as "drawing to or gathering about a center or central point and/or bringing under one control. ${ }^{\prime 19}$ Both the glossary and the dictionary definitions of centralization are applicable to the centralized reference model proposed here, because this model draws together the functions of reference desk assistance, bibliographic and library instruction, online and electronic services, materials selection, and interlibrary loan into one administrative and geographic division. It proposes a service unit that is a microcosm of the university library designed to fulfill the purposes Guy Lyle attributed to reference more than thirty years ago. These were (1) to provide answers to inquiries requiring specific information; (2) to teach students to use the library; (3) to provide bibliographical and other research assistance; and (4) to locate and make available less commonly used materials not in the library. ${ }^{20}$

Different interpretations of centralization in libraries and in the design of library services according to function have existed through the years, but it is notable that the principles of centralization and functional planning have remained relatively stable. Michael Krenitsky's report on university library design posed several premises as justification for a centrally oriented plan. These included emphasis on the use of books and materials, the greatest accessibility for the largest number of patrons, provisions for altering patterns of use necessitated by curricula changes, enrollments, and/or collections, and the ability of library staff to work with maximum 
efficiency. His premises also identified the chief function of the library as service to its clientele. ${ }^{21}$ In planning a reference design, Lyle incorporated these premises in his statement that in a well-designed reference service area, a student working on a paper should be able to find all his references in printed bibliographies, reference books, and periodical indexes in one location. ${ }^{2}$

These premises are still valid for a useroriented design, and they are reflected in the centralized model proposed here. This study, however, extends beyond the limits of printed collections and incorporates the dissemination of all available types of reference information in today's electronic environment as well.

\section{CENTRALIZATION AT LSU}

Meeting the needs of users has been a critical factor in the move from a decentralized library system to a more centralized service at Louisiana State University and Agricultural and Mechanical College. The University serves more than 35,000 faculty, staff, and students and is the state's comprehensive center of higher education. Additionally, it is one of only nine institutions in the country designated as both a land-grant and sea-grant institution. Its instructional programs include approximately 250 subjects that lead to both undergraduate and graduate professional degrees. There are eighty-nine masters and fifty doctoral programs listed in the 1985-86 Graduate School Catalog. ${ }^{23}$

Students, faculty, and staff representing a broad range of subject areas make up the LSU user constituency. With the exception of libraries provided for chemistry, special collections, and the professional schools of law, medicine, and library science, all materials are housed in the Troy H. Middleton Library.

The Middleton building today is a fivefloor structure housing the bulk of a materials collection approaching two million volumes. Reference Services, located on the main floor adjacent to the entrance, provides service to users in all subject areas except business, which is housed with government documents on the basement level, including topics where much of the material is located in chemistry, special collections, or in one of the professional schools.

Prior to 1958 , the university libraries consisted of the main library plus ten branch libraries. In 1958, construction of a new three-story building was completed, and all branch subject collections, except chemistry, were moved into the Middleton Library. The law and medical libraries were, and still are, administered separately. For twenty years, reference service in Middleton was provided through three subject divisions: humanities, social sciences, and sciences.

Few changes occurred until the midseventies, when automation made its first inroad through participation in automated cataloging via the Ohio College Library Center, now known as the Online Computer Library Center (OCLC). This was soon followed in the reference areas by the introduction of BLISS, the Bibliographic and Library Information Search Service.

Further centralization was accomplished in 1978 when the three subject divisions, excepting government documents and business materials, were integrated into one collection. At the same time, the divisional reference departments were united to form Central Reference, the largest unit of the Reference Services division. To keep pace with the growth of the library and the student body, two more floors have been added to the building, and the physical space allotted to the central service has more than doubled.

Since 1984, under the leadership of director Sharon A. Hogan, Middleton has been enhancing its information role by incorporating current technology to extend its user services. This began with the introduction of the disk products Info Trac and CD-Disclosure to the reference areas in 1985-86. Meanwhile, negotiations were under way to automate the library using the fully integrated library system NOTIS, Northwestern Online Total Integrated System, developed at Northwestern University. This contract was soon followed by another providing membership in the Research Libraries Group and participa- 
tion in the electronic Research Libraries Information Network (RLIN). In September 1986, the first NOTIS module became operational with the introduction of Middleton's Library On-Line Access cata$\log$, LOLA. Middleton, particularly the reference service units, was now actively bringing an electronic environment to library users in a centralized setting.

Within this framework, Middleton reference librarians serve an average of 350 to 400 users daily. On peak days during heavy use periods, this count easily exceeds 500 . Of course, the number of patrons not needing assistance but using the collection and electronic services could double those figures. An accurate total for this measure is not yet available. The area, however, is heavily populated with a variety of users during most service hours. These patrons have ranged from elementary school children to the director of a Soviet library. Their age, race, education, nationality, technical expertise, and ability or inability to speak English are as varied as the problems they present.

\section{ADVANTAGES VERSUS DISADVANTAGES}

Obviously, there are advantages and disadvantages to centralizing the reference operation in a large university library. Arguments usually focus on the economic advantages rather than the quality of service since financial factors are often more tangible and beneficial from an administrative viewpoint.

Centralization of reference services does result in dollar savings, and this is one issue seldom disputed in the organizational debate. In Hurt's article proposing staff specialization as a substitute for library departmentalization, he spoke of the "costly duplication of personnel, equipment, and books which comes with departmentalization. ${ }^{24}$ Swank, the divisional system proponent, also cited the fact that "it is commonly charged that the subject-divisional type of organization is more costly than the traditional types," though he personally questioned that belief..$^{25^{\circ}}$

Immediate financial benefits can be realized by reference centralization from staff reductions and ceasing duplication of ti- tles for multiple locations. LSU achieved both benefits ten years ago by uniting the divisional reference departments into one service point. Four positions, two professional and two support, were assigned to other areas at that time. Savings also resulted as duplicate orders were canceled. It was no longer necessary to provide a common core of dictionaries, almanacs, and other sources to three locations. Further staff time was realized by integrating the division catalog files into one, eliminating the need to maintain three separate catalogs.

In addition to these pluses, arguments also point to the fact that consolidation results in space gains. New offices may be created, other units relocated, and/or added storage space for materials made available. These bonuses were also apparent in Louisiana and provided for the eventual expansion of the business administration/government documents service, more office space, and the creation of a study room for the visually impaired. Additionally, a sizable compact storage area almost half the size of the former social science area was created.

The financial and space savings are the usual arguments proposed when centralization is being considered. Frequently, the need to add footage and reduce expenditures are the reasons for consolidation. Existing conditions may force administrators into immediate reorganization to resolve these concerns. When this occurs, the question of the effects of centralization on staff and service become secondary.

A library's staff, however, is an institution's life force, responsible for collecting, organizing, preserving, and accessing a library's materials. In effect, the staff creates a library and provides the service essential to making it usable. Without that service, the information contained in any collection is difficult if not impossible to access.

The importance of staff to a library's success demands consideration. Unfortunately, the literature on this aspect of centralization is slim. As pointed out previously, research has concentrated on the centralization-decentralization question as it relates to the library user, collec- 
tion development, or technology. Thomas Watts advocated centralizing library collections, noting such advantages as convenience, the consolidation of collections in one location, reduced expenditure, and improved interdepartmental communications. ${ }^{26}$ Michael Hibbard saw merit in Watt's argument and favored the efficiency aspects of centralization. ${ }^{27}$

\section{"Hugh Atkinson opposed centraliza- tion and emphasized patrons' prefer- ences for 'more focused units of li- brary service.' "'}

In "A Brief for the Other Side," Hugh Atkinson opposed centralization and emphasized patrons' preferences for "'more focused units of library service. ${ }^{\prime 28} \mathrm{He}$ cited Snunith Shoham's literature survey as evidence of that preference. ${ }^{29}$

\section{STAFF/SERVICE BENEFITS}

None of these arguments, or those proposed earlier, resulted from an in-depth examination of the advantages or disadvantages of centralization to a library's staff and services. Because of that lack, a consideration of points relating to these factors is in order. In brief, centralizing the reference staff and services can yield the following seven benefits:

1. Availability of a large professional staff to provide a high quality of service to users.

2. Extended hours of reference service beyond those usually provided by most university libraries or by branch libraries. ${ }^{30}$

3 . Because of the sizable number of professionals, the unit can be staffed at all times with a librarian.

4. The large staff provides a greater variety of subject expertise.

5. Such a staff allows for a broader range of talents and abilities supporting more effective staff specialization.

6 . The greater numbers allow for more varied professional interests and activities.

7. The sizable staff provides increased opportunities for in-service training and staff development.

All of these benefits result in better service to the public. But, what are the disadvantages? Let's consider five:

1. Professionals must be familiar with reference resources in many subject areas.

2. Online searchers must be acquainted with databases in a multitude of subjects.

3. Bibliographic instruction must be available in all subject areas.

4. Super subject specialists can seldom be developed because of demands from the numerous subject areas.

5. Sheer number of demands for assistance, complicated by the variety of patrons encountered in a centralized operation, can be stressful.

Because these five disadvantages can overshadow centralization benefits, they will be addressed first and accompanied by suggestions as to how they can positively affect a central operation.

\section{EXPERTISE QUESTIONED}

The point questioned most frequently is the staff's ability to work well with reference resources in numerous subjects. Centralized reference opponents emphasize the impossibility of knowing all the sources and of being capable of doing research in them. Attacks focus on the need for reference librarians to be subject specialists first and information specialists last, if at all. They ignore librarians' study on the organization and structure of information and the research process. Professional expertise in developing search strategies and relating them to appropriate sources is seldom considered. Furthermore, the current impact of technology on staff and their ability to use it effectively to retrieve information is inadequately explored.

Patrick Wilson touches on the role of librarians in accessing information in his book Public Knowledge, Private Ignorance: Toward a Library and Information Service Policy. Wilson says, "The librarian is not a specialist in information in general, but in information about records. The librarian's job is a job of management of informationbearing objects, and the continually improved performance of that necessary job 
is a natural and reasonable goal for the future." 31

A 1985 article discussing the effect of an online catalog on a reference staff at the University of Illinois added another dimension to Wilson's argument by asserting, "The era of the 'holistic librarian' is here. ${ }^{132}$ The article points to the range of informational expertise needed to provide effective service in today's electronic environment. The range extends from such specifics as the contents of database records and access points to the broad generalities of library collections and the automated systems used to access them.

Evelyn Daniel also explored the academic librarian's new role as an information resources manager. She emphasized that "librarians will have to be competent to work in new ways' ${ }^{\prime \prime 3}$ and pointed to the possibility of a consultative method akin to the online searcher/clientele search interview. All of these concepts have merit. Librarians must understand the organization of information to access it in a systematized manner. This is basic to librarianship and should be part of one's professional education and experience. It is as essential to reference service as the knowledge of the reference process itself. Indeed, it is part of the process.

Essential to realizing this philosophy, however, is having a collection extensive enough to permit full exercise of our professional abilities. Granted, reference librarians in a centralized service may never develop the in-depth knowledge of each tool that colleagues who work in a limited subject area do, but they will never be subjected to the limitations in resources encountered in those restricted informational environments either. We live in an interdisciplinary era, and academic librarians need the broad resources and support to grow in that direction.

Therefore, a centralized reference arrangement, due to the scope of its knowledge base, provides a fertile environment in which to better develop expertise in information handling. Such a setting, with its large staff reflecting a variety of academic expertise and talents, offers more opportunities for enriched professional development while maintaining a reliable quality of service for users. It is the environment needed to develop the holistic librarians and information resource managers needed by users at this point in our technological development.

\section{THE ONLINE SERVICE}

This same argument extends to the demands centralization places on the online searcher. Again, understanding the organization and structure of, in this case, the databases is foremost to quality searching. But knowledge of the databases and structure alone is not sufficient. Searchers must be able to manipulate that knowledge. Such skill requires certain personal qualities and attributes. Ann Van Camp included as attributes a logical mind, the ability to exploit success, a willingness to go beyond formal training, and a retentive memory. ${ }^{34}$ Donna Dolan emphasized concept analysis and flexibility of thinking. ${ }^{35}$

Most agree that searchers usually have good problem-solving abilities and are creative thinkers. Naturally, some online intermediaries do not have all the traits, but their development is to be encouraged for the benefits they bring to online access as well as for their potential enrichment of the centralized service.

Learning additional databases is demanding, but the payoffs to the individual, the library, and the clients are considerable. Brian Nielsen cites these in his article on searching and librarianship, "Librarians may be working harder, and they are devoting more of their time to patron interactions of a higher order. They spend more time with the subject literatures. They spend less time doing routine reference work and supervision. In their interactions with patrons they have found new respect, and have greater control over the interactions than they have over the bulk of traditional reference interactions. ${ }^{136}$

A centralized service is an ideal setting for encouraging this growth. The availability of staff members provides the work force needed to handle routine reference work more efficiently. Additionally, consolidation of the online service with reference reduces the number of personnel involved in supervisory tasks. This affords 
searchers more time to improve their online capabilities, thereby increasing their individual expertise and enhancing their image with library users.

Therefore, the centralization of the online service in reference extends the beneficial professional environment by necessitating that more databases be learned, which further improves online searching abilities. At the same time, the study of the databases increases knowledge of printed sources. These factors result in improving the professional capabilities and selfimage of the librarians and enhancing that image in the university community. The final product in all instances is improved service to users.

\section{BIBLIOGRAPHIC INSTRUCTION}

The next disadvantage frequently alluded to is the need to offer bibliographic instruction in all subject areas. Instead of a disadvantage, however, this works to a central operations' advantage also. Carolyn Kirkendall and Carla Stoffle point out the benefits to faculty relations provided by BI programs. ${ }^{37}$ In their essay on instruction, they cite Nancy Gwinn's study and her statement: "Building faculty relations-getting out of the library and into campus affairs-is still the key to building support for the library's instructional program and other services." 38

A centralized arrangement requires varied bibliographic instruction programs. At LSU, these include an undergraduate library credit course; numerous one-shot lectures in freshman English classes as well as for agriculture, education, or journalism graduate students; and physics, engineering, and other departmental faculty seminars. These extensive BI programs, like the online service, stretch the staff's professional experience and provide beneficial results to librarians and library users as well.

BI program benefits result from the playing out of the following scene: a request comes in for a petroleum engineering lecture. It is assigned to a staff member who prepares an Infofile-a selective, annotated bibliography on the topic-and also provides an online demonstration at the presentation. Researching the topic, writing the annotations, and preparing the Infofile, plus reviewing the relevant databases, familiarizes the librarian with print and online resources in petroleum engineering, thereby enriching professional expertise in that subject area.

\section{"Building faculty relations-getting out of the library and into campus affairs-is still the key to building support for the library's instructional program and other services."}

The lecture presentation and online demonstration improve the librarian's image with the faculty and students, resulting in improved relations with that department. An added benefit at LSU is the availability of the growing Infofile series to all students on request.

Providing BI in the large variety of subject areas demanded by a central service results in frequent repetition of the above scenario, improving faculty and student relations on a campuswide basis. This benefits the instruction program and the participating librarians and enhances the library's image.

\section{SUBJECT SPECIALIZATION}

In listing other factors considered disadvantages to centralization, the limitation on developing the super subject specialist was cited. Central service detractors raise this point as one of the greatest drawbacks to the model. It should be noted that it is advantageous to librarians in subjectspecific areas, or to advocates of that service mode, to exaggerate the degree of expertise needed to provide effective academic reference service. Also worthy of consideration is the fact that today's information base is more interdisciplinary and has fewer boundaries than ever before. The subject specialist may be too hampered by the limits built into the subject collection itself to serve users fully in our changing environment.

Equally relevant to this argument is Wilson's definition of the librarian's spe- 
cialty as that of managing information resources rather than the information itself. ${ }^{39}$ Extensive subject specialization may be more desirable in special libraries in business and industry. Universities, as the name implies, are responsible for a universal approach to education, particularly in today's society. The reference division in a university library, therefore, should provide services in keeping with that role.

This is not to imply that subject expertise is unnecessary. It is required in universities, but an engineering degree is not essential in providing reference service, searching, and BI for engineering clientele. What is necessary is familiarity with the engineering vocabulary, understanding how the information is organized, and knowledge of the relevant print and online resources. This can be gained through experience and on-the-job training. As F. William Summers states in his article "Education for Reference Service," being conversant with the discipline is expected. How a reference librarian becomes conversant with that discipline-whether through academic studies or experienceis less relevant. ${ }^{40}$

Summers' article includes a discussion of the future of reference education and suggests incorporating the following changes into library school curricula:

1. Less emphasis upon specific sources and more on a ready reference core of titles. He points to the increasing use of computers and the need to know database content and characteristics as well as search strategy.

2. Emphasis on group and interpersonal communication skills. He asserts that future librarians need to combine elements of the communicator-parexcellence with the knowledge of sources and the organization of information and how to access it.

3. Emphasis on the need for subject knowledge. He suggests alternative ways of acquiring this, including joint master's programs, sixth-year or advanced mas-

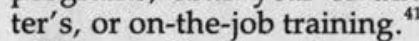

Though Summers' recommendations were made without regard to organizational structure, his educational prescrip- tion is particularly applicable for the central setting in the electronic environment. Knowledge of a coordinated core of titles, of computers, and emphasis on communication skills all precede the need for subject specialization in Summers' list. Possibly, the need for superior subject expertise in academic libraries has indeed been exaggerated.

A study of the subject specialist question is certainly overdue. Until one is conducted, however, decisions can only be reached on this issue by examining the available evidence. Today's evidence seems to indicate that the electronic environment increases the need for the "holistic librarian, ${ }^{\prime 42}$ or the information resources manager ${ }^{43}$ rather than the traditional subject specialist.

An examination of use of LSU's reference services division appears to substantiate this growing need for information specialists. During fiscal year 1985-86, the Middleton staff handled 132,827 questions-more than 81,000 at the reference desks and another 51,000 at the adjacent information desk. The large majority of these questions required the assistance of a professional capable of crossing interdisciplinary boundaries. The demand for subject specialization was more evident in the 998 intermediated subject searches conducted online during the same period. Of that number, at least 30 percent, possibly more, did not require any subject expertise due to the general nature of the topics.

\section{"At LSU, it appears that our elec- tronic environment may be shaping librarians who specialize in informa- tion management first, then subject content.'}

The advent of the online catalog in fall 1986 has not altered that stance. If anything, it has added credence to it. It has further increased the need for librarians to know more about the database, the records' contents, and how the information is processed. Our experience has been similar to that at Illinois in that regard. At 
LSU, it appears that our electronic environment may be shaping librarians who specialize in information management first and subject content second.

\section{ADDITIONAL ADVANTAGES}

The advantages of centralization at LSU have far outweighed the difficulties debated in the literature. By far, the greatest advantage has been the large professional staff allowing staffing by a librarian at all times. Additionally, this has enabled Middleton to provide more hours of reference service than 84 percent of the libraries surveyed by Paula D. Watson in her 1983 study. ${ }^{44}$ It also permits the staff to deal effectively with the number and variety of questions and users coming into the central service. Librarians seldom work more than twelve hours a week at the desk, which counteracts the stress and burnout possible in busy reference areas.

Additionally, the staff size provides a broad variety of subject expertise. LSU reference librarians hold bachelor's degrees in such varying subject areas as journalism, mathematics, psychology, earth sciences, and English. Four have subject master's degrees as well.

Experience spans a gamut of subjects and also includes functional expertise. Background includes work in the humanities, social sciences, sciences, and technology and in both academic and special libraries. Additionally, a wealth of professional experience is available, including varying lengths of service in BI, cataloging, circulation, collection development, federal and state publications, interlibrary loan, and, of course, a broad range of reference service. Academic backgrounds, professional experience, and special talents and abilities of this scope require the large and varied staff that is more readily achieved in the centralized setting.

An added advantage for centralized staff is the opportunity for in-service training and staff development available in a personnel unit of this size and quality. Training is particularly important to today's academic librarians, who must be experts in the technology as well as teachers and researchers.
Librarians at LSU are heavily involved in automation, which has necessitated considerable training. A variety of online services have been offered for a number of years, and recently the staff has been involved with the installation of NOTIS and the introduction of LOLA, the online cata$\log$.

Woodsworth's idea that technology would obliterate the arguments favoring centralizing ${ }^{45}$ has not been the LSU experience to date. Instead, the increasing use of technology has required a more highly trained staff, a goal which can be achieved most efficiently through centralization. Training is expensive, and departmental libraries increase that cost because of the administrative complications involved. Scheduling replacements to allow for training in branches or satellite facilities can be a problem. Middleton's central operation reduces that difficulty. Frequent in-service training programs are instituted with little disruption to staff or service, insuring that user services are up-to-date, comprehensive, and professionally provided.

\section{"The LSU experience indicates that technology presently requires more centralization in order to maintain well-trained personnel to operate the limited number of expensive techni- cal devices available for use."}

Middleton reference staff are currently involved in two regularly scheduled inservice training programs. The more extensive of these does double duty in training the unit's graduate assistants, who number ten, or more including the parttime assistants covering nights and weekends.

The graduate assistant program consists of weekly thirty- to forty-five-minute lectures on topics such as the reference interview, service policies, patron communication, online systems and sources, and resources in the humanities, social sciences, and sciences. These lectures are provided by the staff's senior members 
and are often enriched by special lectures prepared by graduate assistants holding master's degrees in various subject areas. Members of the reference staff also attend these presentations when they involve subject areas in which improvement is needed. This exchange of reference skills, experience, talents, and academic backgrounds is vital to the staff's continued professional growth and to the provision of quality service.

Additionally, a series has been developed specifically for the permanent staff. The training-in-progress sessions, or TIPS, are usually ten- to fifteen-minute presentations offered at biweekly staff meetings. They cover new reference sources, reference titles needing attention, seldom-used materials needing promotion, and difficult-to-use items. In addition to these, more formalized training and workshops are held throughout the year on the online systems and databases, NOTIS, RLIN, and microcomputer use and software.

The increasing use of technology in academic libraries has not resulted in a dramatic move toward decentralization to date. At least there is no indication of that movement in the literature.

The LSU experience indicates that tech- nology presently requires more centralization in order to maintain well-trained personnel to operate the limited number of expensive technical devices available for use. Admittedly, future developments, the increased availability of technically trained staff, and the reduced cost of electronic equipment could radically change that picture. For the present, however, academic libraries must deal with the problems of equipment shortages and an often inadequately trained staff. These may be dealt with most effectively in a central setting.

Centralization of the collections, of professional expertise, and of the reference units has enabled the LSU libraries to provide a high quality of service in this complex environment. It meets researchers' modern information needs by incorporating something of the one-stop-shopping concept outlined by Battin in her description of the Scholar's Information Center. ${ }^{46}$

At the same time and in more physical terms, it has fulfilled Lyle's traditional criteria for a well-designed reference area by providing students a single place where they can research a paper and find all the needed references in bibliographies, reference books, and periodical indexes. ${ }^{47}$

\section{REFERENCES}

1. Maurice F. Tauber, ed., "Centralization and Decentralization in Academic Libraries: A Symposium," College Research Libraries 22:327 (Sept. 1961).

2. Keyes D. Metcalf, Studies in Library Administrative Problems: Eight Reports from a Seminar in Library Administration (New Brunswick, N.J.: Rutgers Univ. Graduate School of Library Service, 1960), p.133.

3. Barbara B. Moran, Academic Libraries: The Changing Knowledge Centers of Colleges and Universities (ASHE-ERIC Higher Education Research Report, no.8, 1984), p.32

4. Rose B. Phelps, "The Effect of Organizational Patterns on the Adequacy and Efficiency of Reference Service in the Large American Public Library," Library Quarterly 17:281-95 (1947).

5. Raynard C. Swank, "Educational Function of a University Library," Library Trends 1:37-47 (July 1952).

6. J. R. Blandchard, "Departmental Libraries in Divisional Plan University Libraries," College Research Libraries 14:243-48 (July 1952).

7. Peyton Hurt, "Staff Specialization," A.L.A. Bulletin 29:417-21 (July 1935).

8. Guy R. Lyle, The Administration of the College Library, 3d ed. (New York: Wilson, 1961), p.129.

9. Moran, p.33.

10. Anne Woodsworth, "Decentralization Is the Best Principle of Organization Design Where It Fits," in "Centralization or Decentralization of Library Collections: A Symposium," The Journal of Academic Librarianship 9:196-202 (Sept. 1983).

11. Hugh C. Atkinson, "A Brief for the Other Side," in "Centralization or Decentralization of Library Collections: A Symposium," The Journal of Academic Librarianship 9:196-202 (Sept. 1983).

12. Edward G. Holley, "Reaction to 'A Brief . . . '," in "Centralization or Decentralization of Library Collections: A Symposium," The Journal of Academic Librarianship 9:196-202 (Sept. 1983). 
13. Charles R. Martell, Jr., The Client-Centered Academic Library: An Organizational Model (Westport, Conn.: Greenwood, 1983), p.67.

14. Hugh F. Cline and Lorraine T. Sinnott, The Electronic Library: The Impact of Automation on Academic Libraries (Lexington, Mass.: Lexington Bks., 1983), p.174-75.

15. Patricia Battin, "The Electronic Library: The Electronic Library - A Vision for the Future," in New Information Technologies and Libraries, ed. H. Liebaers, W. J. Haas, W. E. Biervliet (Boston: NACO Scientific Affairs Division, 1984), p.203.

16. Richard W. McCoy, "The Electronic Scholar: Essential Tasks for the Scholarly Community," Library Journal 110:39-42 (Oct. 1, 1985).

17. Heartsill Young, ed., The ALA Glossary of Library and Information Science (Chicago: American Library Assn., 1983), p.38.

18. Ibid., p.68.

19. Webster's Third New International Dictionary of the English Language Unabridged (Springfield, Mass.: Merriam, 1976), p.363.

20. Lyle, p.129.

21. Michael V. Krenitsky, "Approach to a University Library Design," (Bryan, Tex.: Caudill, Rowlett, Scott and Associates Report, no.RR-13, 1958), p.6-7. (ED 014 860).

22. Lyle, p.132.

23. The 1985-86 Graduate School Catalog (Baton Rouge: Louisiana State Univ. and Agricultural and Mechanical College, 1985), p.8-9.

24. Hurt, p.417.

25. Swank, p.46.

26. Thomas D. Watts, "A Brief for Centralized Library Collections," in "Centralization or Decentralization of Library Collections: A Symposium," The Journal of Academic Librarianship 9:196-202 (Sept. 1983).

27. Michael Hibbard, "Centralized Library Collections? Well, Maybe: A Response," in "Centralization or Decentralization of Library Collections: A Symposium," The Journal of Academic Librarianship 9:196-202 (Sept. 1983).

28. Atkinson, p. 200.

29. Snunith Shoham, "A Cost-Preference Study of the Decentralization of Academic Library Services," Library Research 4:175-94 (1982).

30. Paula D. Watson, "Reference Service in Academic Research Libraries" (Unpublished survey conducted by ALA/RASD Reference Services in Large Research Libraries Discussion Group, 1983).

31. Patrick Wilson, Public Knowledge, Private Ignorance: Toward a Library and Information Service Policy (Westport, Conn.: Greenwood, 1977), p.121.

32. Beth S. Woodard and Gary A. Golden, "The Effect of the Online Catalogue on Reference: Uses, Services, and Personnel," Information Technology and Libraries 4:338-45 (Dec. 1985).

33. Evelyn H. Daniel, "Educating the Academic Librarian for a New Role as Information Resources Manager," The Journal of Academic Librarianship 11:360-64 (Jan. 1986).

34. Ann Van Camp, "Effective Search Analysts," Online 3:18-20 (Apr. 1979).

35. Donna R. Dolan and Michael C. Krenin, "The Quality Control of Search Analysts," Online 3:8-17 (Apr. 1979).

36. Brian Nielsen, "Online Bibliographic Searching and the Deprofessionalization of Librarianship," Online Review 4:222-23 (Sept. 1980).

37. Carolyn A. Kirkendall and Carla J. Stoffle, "Instruction," in The Service Imperative for Libraries: Essays in Honor of Margaret E. Monroe, ed. Gail A. Schlachter (Littleton, Colo.: Libraries Unlimited, 1982), p.42-93.

38. Nancy E. Gwinn, "Academic Libraries and Undergraduate Education: The CLR Experience," College Research Libraries 41:10 (Jan. 1980).

39. Wilson, p.121.

40. F. William Summers, "Education for Reference Service," in The Service Imperative for Libraries: Essays in Honor of Margaret E. Monroe, ed. Gail A. Schlachter (Littleton, Colo.: Libraries Unlimited, 1982), p.166-67.

41. Ibid., p.167.

42. Woodard, p.343.

43. Daniel, p. 360.

44. Watson, "Reference Service in Academic Research Libraries."

45. Woodsworth, p.199.

46. Battin, p.213.

47. Lyle, p.132. 